\title{
VII. 新エネルギー源
}

\section{7 原子力発電の動向}

昭和 41 年度における原子力発電の動向で目立つたも のはつぎのとおりである。

1）アメリカの TVA が 110 万W の BWR 2 基を 発注した際に発表した“TVA 報告書”に括いて, 原子力発電が火力発電に対し決定的有利性をもつて いることを明らかにした。

2) アメリカにおいて, 大形転水炉 (PWR および BWR) の発注が相つぎ，1966年の新規発注分の半 分以上を原子力が占めた。

3）英国注，第 2 次，原子力発電計画沿沿つて，改良 ガス炉 (AGR) の発注を行なつているが，やや Slow down ぎみである。これは，英国経済の苦境 がその原因と思われる。

4）高速炉の開発が，米，英，ソ連などを中心に，軌 道に乗つてきた。

5）わが国においては，敦賀 BWR (325 MWe)，美 浜 PWR (324 MWe), 福島 BWR (400 MWe) の 各発電所が，建設を開始し，わが国も原子力発電の 実用期に入つてきた。

さらに，動力炉開発事業団が新設されることにな り，高速炉および重水炉の開発が強力に推進される こととなつた。

以下，これらについて概要を説明しょう。

\section{I . アメリカの軽水炉と TVA 報告}

1966年中に米国で発注された発電所は，火力が 1,700 万 $\mathrm{kW}$ であつたのに対し，原子力は 1,750 万 $\mathrm{kW}$ と、わずかながら火力を上迴つた。この理由として, 電力需要が予想外に伸びたため, そのしわ寄せが原子 力発電所の発注增加に現われたこと, 中規模電力会社 が対抗意識から先を争つて原子力に乗り出してきたこ となどの特殊事情もあつたが，乙かし根本的には，原 子力発電 (とくに軽水炉) がようやくその経済性にお いて，火力発電をしのぐ勢いになつてきたことを如実 に示すものであろう。もし，前記の二つの特殊事情に よつて原子力が伸びたとするならば，1966年が原子力 発電所発注のピークとなるはずであるが本年に入つて からの発注状況から考えると，その見方は当を得てい ないよらである。
原子力発電と火力発電の競合性についての経済分析 としては，1964年 2 月に発表された“オイスター・ク リーク報告書”が令の先鞭をつ订たものであつた。才 イスター・クリーク報告書で泣，1967年（オイスター ・クリーク BWR の完成年)には，アメリカの $1 / 3$ $1 / 2$ の地域で原子力が火力と競争できることを明かに し，センセーションをまき起した。1966年 6 月, TVA （テネシー渓谷開発局）は，世界最大の原子力発電所 （電気出力 110 万W のBWR 2 基）を発注した折に, “T V A 報告書”を公表し, 「評価の結果, 原子力発電 所は石炭火力発電所任対し決定的な有利性もつてい ることが明かになつた」と述べている。

表VII-1 原子カと火カの発電原価比較( $\mathrm{T} V \mathrm{~A}$ 報告害) (初期年間の平均犆) (単位; ミル $/ \mathrm{kWhr}$ )

BWR PWR 水力

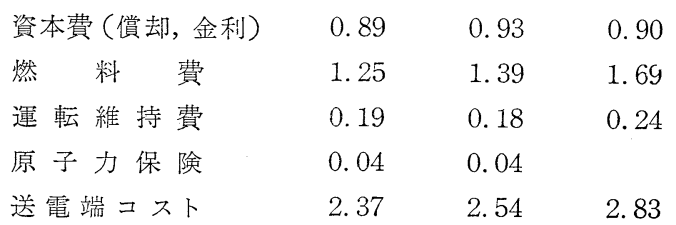

表VII-2 TVA 報告書の原子カと火力発電所主要 データ

\begin{tabular}{|c|c|c|}
\hline $\begin{array}{r}\text { 正味プラント容量 } \\
\text { (2 基) 万践 }\end{array}$ & 212.9 & 198.9 \\
\hline $\begin{array}{c}\text { 正味 熱消費率 } \\
\mathrm{Btu} / \mathrm{k}\end{array}$ & 10,558 & 10,548 \\
\hline 燃セン料 百万Btu & 11.6 & 13.17 \\
\hline 資本費ドル/kW & 116.0 & 121.5 \\
\hline
\end{tabular}

TVAの発表した資本費ならびに発電原価を表VII-1 および 表VII-2 に示す。表VII-2 でわかるように，熱 消費率は, 原子力の方がかなり大きい。これは原子力 では飽和蒸気を使用するため熱勃率が低くなるためで ある。しかし, 石炭に比し, ウランの価格がきわめ て安いため, 100万Btu あたりの燃料費は, 火力で, 18.90 ミルなのに比し, BWR で 11.86 ミル, PWR で 13.17 ミルと火力に比し相当低くなる。このため, 発電原価のうちの然料費も, 火力が 1.69 ミル/kWhr なのに比し，BWR では，12.5ミル/kWhr に過ぎな 
い。表VII-1 よりわかるように，資本費は，火力と BWR ではほとんど差がないのに, 発電原価に扔いて, 火力が 2.83 ミル/kWhr, BWR が 2.37 ミル/kWhr と大きい差の出るのは，大部分がこの然料費の差に起 因するものである。従来, 原子力発電は, 建設費は火 力に比しやや割高になるが，その分を燃料費の安いこ とで補らことにより，火力と競合できると考えられて きたが，原子力発電の大容量化や種々の技術開発の結 果，建設費も火力並みに低下してきたことは注目す心゙ きことである。もし，建設蒷が火力並みに低下したと すると, 原子力発電所が火力発電所に比し経済性の点 で決定的に勝つているというのは, 当然の結論といえ よう。なお TVA 報告書では, 原子力と火力発電所の 運転維持についても分析を加えているが，「運転維持 の総経費は，石炭取り扱い，燃燒設備などが不要のた め原子力の方が安くなる。人員も, 運炭や保守を中心 としてかなり削減できる。このため, 火力発電所では 250 人の運転員が必要だが，原子力では，150人です むと述べられている。」このため, 表VII-1 の運転維 持費として, BWR では 0.19 ミル/kWhr であるのに 対し, 火力では 0.24 ミル/kWhr とやや大きめな值 を揭げてある。(火力のこの值は, 既設の 65 万W 2 基の火力発電所の経験に基づいて求められたものであ る。)

\section{II. 高速炉の開発}

ウラン資源を全部有効に利用するためには，天然ウ ラン中の U-235（わずか $0.7 \%$ ) のみでなく，U-238 (99.3\%)も.Pu-289 亿変換して, 核然料とし利用しな ければならないが，このためには，高速炉を用いて増 殖を行なら必要がある。転水炉，マグノックス炉（天 然ウラン，黒鉛炉）などの実証炉の実用化が急速に進 むにつれ，このような形の熱中性子炉のみに頼つて原 子力発電を進めてゅくと，1850１900年頃には，ウラ ン資源が不足する心配がある。そのため, 第 3 回ジ二 ネーブ会議（1994）を契期として，米，英，ソ連をは じめ, 世界各国で高速炉の実用期を早めようといら動 きが盛んになつた。

米国では，液体金属冷却高速炉 (LMFBR) を本命 と考えており，それで増殖比 1.2 以上を得ることを 目標としている。1980年代のはじめまでに, 電気出力 100 万W クラスの商用高速炉を建設することを目指 しており，その前に，30 50万 $\mathrm{kW}$ クラスの原形高速 炉を建設することを中期目標としている。また一部で は, 核過熱形転水炉の延長として, 蒸気冷却形高速 炉 (SCFBR) も研究している。SCFBR は, 蒸気と
いう経験の豊富な却却材を利用できる利点があるが， 増殖比が低い（1.1 程度）のが欠点である。

イギリスでは1970年代のはじめに, 電気出力 25 万 $\mathrm{kW}$ の原形炉を完成する予定で建設を急いでいる。

西独では, LMFBR と SCFBR を並行して研究し ている。今のところ，世界各国とも LMFBRを，高 速炉の本命と考えているが，ナトリウムを冷却材とし て利用するため, 解決しなければなら問題も多く残 つている。その主なものは，つぎのとおりである。

（1）燃料抢よび材料 燃料は， $1,200^{\circ} \mathrm{F}$ のナトリ ウム冷却材中で $10^{22} \mathrm{nvt}$ 程度の照射に耐え衩ばなら ぬ。セラミック燃料には，少なくとも 100,000 MWD $/ \mathrm{t}$ 程度の燃焼度が要求される。このように, 高燃焼 度に耐える高信賴度の燃料要素を開発しなければなら ない。

（2）炉物理的問題理論解析, 核定数, 臨界害験の 3 つの分野でさらに研究が必要である。これらは, 高 速炉の安全性の問題の解決のために不可欠である。

（3）ナトリウム技術 ナトリウム取り扱い技術は かなり蓄積されてきたが，将来の大形 LMFBR のた めには，大形ナトリウムループが必要となりそのため の, 熱交換器, ポンプ, バルブ, 計器などを開発しな ければならない。

\section{III. わが国における原子力発雷の動向}

発電用原子炉として，すでに，東海村で JPDR (BWR, 12.5 MWe), 東海発電所 (コールダ改良形, $166 \mathrm{MWe}$ ) の 2 基が運転を続けているが，昨年，日本 原子力発電会社の敦賀発電所 ( $B W R, 325 \mathrm{MWe})$, 関 西電力の美浜発電所 (PWR, $325 \mathrm{MWe}$ ), 東京電力の 福島発電所 (BWR, $400 \mathrm{MWe}$ ) の 3 つの大形転水形 原子力発電所が建設を開始し, わが国の原子力発電も ようやく実用期に踏み出そうとしている。わが国の商 用原子力発電の 1 号炉は, 東海発電所で, 英国形の天 然ウラン，黒鉛炉でスタートしたが，今後は，米国形 の転水炉が, 当分の間, わが国の原子力発電を独占し そうである。その理由として, 英国形のガス冷却炉 は, 天然ウラン，黒鉛炉（マグノックス炉）から改良 ガス泠却炉 (AGR) 几と進歩し, 英国においては全 面的に採用され，実用期を迎えているが，何分にも英 国の電力事業そのものが国営で，そのため，，本当の 経済性がなかなか把握しにくいこと, および, ガス冷 却炉の方が，転水炉に比し大形になり建設費が高いな どがあげられよう。さらに, 従来, わが国の電力会社 は米国の，GF，WH との結びつきが強かつたことも この傾向に拍車をかけている。 
表VII-3 送電端電力量の推移 $\left(10^{6} \mathrm{kWhr}\right)$

\begin{tabular}{|c|c|c|c|c|}
\hline 年度 & 39 (実績) & 50 & 60 & 75 \\
\hline 一般火力 & 62,173 & 76,598 & 87,800 & 104,900 \\
\hline 水 & 103 & 3,590 & 8,050 & 47,370 \\
\hline 力 & 86,001 & 271,364 & 372,340 & 434,260 \\
\hline $\begin{array}{l}\text { 原 子 } \\
\text { (比率\%) }\end{array}$ & - & $\begin{array}{r}30,353 \\
(7.9)\end{array}$ & $\begin{array}{r}307,150 \\
(39.5)\end{array}$ & $\begin{array}{r}1,163,480 \\
(66.4)\end{array}$ \\
\hline 揚 水 用 & $\Delta 161$ & $\Delta 5,128$ & $\Delta 11,500$ & $\triangle 67,670$ \\
\hline 霄 & 701 & 1,362 & 1,360 & 1,360 \\
\hline 計 & 148,817 & 379,139 & 765,200 & $1,683,700$ \\
\hline
\end{tabular}

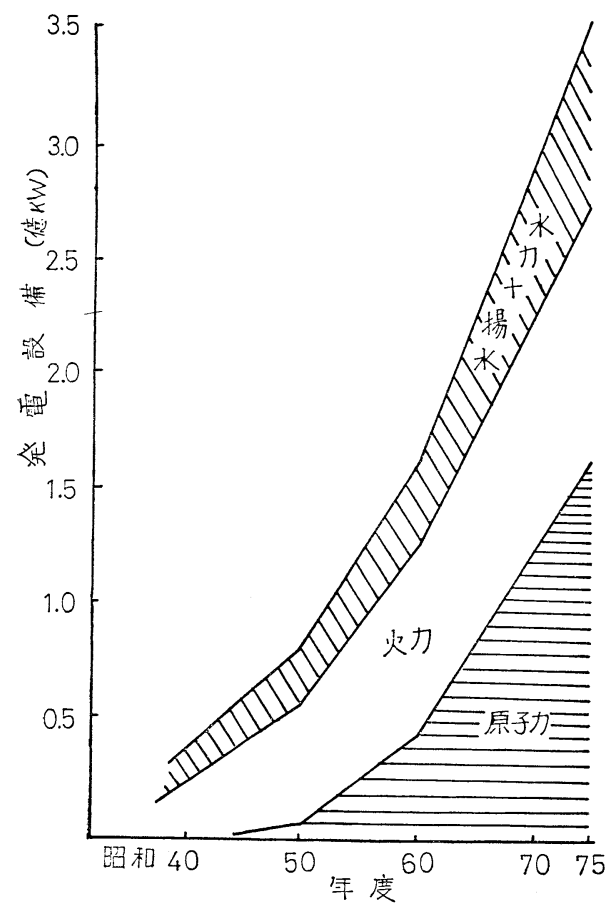

図VII-1 わが国の発電設備の推移

わが国の原子力発電量がどのように伸びて行くかに ついては, 餉年 3 月, 原子力産業会議の吉村部会から 報告書が出されている。送電端電力量注, 表壮-3 に 示すと扔りで，昭和50年には約 $8 \% ， 60$ 年に $40 \%$, 75年には 66\% と急速に増加してゅく。発電設備の方 も, 図VII-1 に示すように急激に伸び， 50 年に $6 \%$, 60 年に $27 \% ， 75$ 年には $46 \%$ と約 $1 / 2$ が原子力発電所 になる。このように原子力発電が急激に増大するの は, 原子力発電コストの低下とともに, 発電用重油輸 入の問題がからんでいる。もし, 原子力発電を全く行 なわないとすると昭和75年度における電力用重油の消 費量は， 3 億 4,600 万 $\mathrm{k} l$ と現在の消費量の 35 倍という 想像を絶した量になり，そのための，タンカー所要
量, 港湾施設，外貨などを考えると，気の遠くなるよ らな話である。ところがもし原子力発電が計画どおり 導入されれば，この量は， 8,300 万 $\mathrm{k} l$ ですむことに なる。

わが国における動力炉開発計画は, 昨年末, 動力炉 開発推進本部で討議されてきたが，いよいよ本年度か ら，動力炉開発事業団が新設されることになり，高速 炉および新形転換炉 (A T R) の開発を強力江推進す ることになつた。

\section{2 直接発電の動向}

直接発電に関する問題の研究は守すます広範囲にか つ具体的になりなかでも MHD 発電の研究につい ては, 各種の国際会議などをつうじて，その実現への 検討が一層活発になつてきた。

\section{MHD 発電}

MHD 発電については, 1966年 7 月, ザルウブルク で第 3 回国際シンポジウムが開かれ，ソ連70編，アメ リカ 40 編, フランス 30 編, ドイッ 19 編，イギリス 16 編, わが国12編その他欧州各国から多数の研究発表が なされ，合計 213 編もの報告があつた。特に今回の会 議が MHD 発電研究の分野においてかなり大きい役 割を果したことは各方面からも認められることであ り，機会あるごとに，この会議を中心にした報告がな され，報告書1)が出版された。一方米国に打いては 7th Symp. on Engg. Aspect of MHD が開かれ, ここでも多くの研究報告がなされた。また国内におい ても数多くの研究発表 ${ }^{2)}$ がなされ, 学会の報告書 ${ }^{3)}$ や 総説 ${ }^{4476)}$ が出版された。つぎに各項目別に本年度の報 文から代表的なものを拾つてみよう。

\section{1. 開放少イクル}

1）発電サイクル

MHD 発電を実現する上で一つの課題といわれた大 型超電導マグネットの開発が，米国 AVCD 社などで 成功してから，この問題に関してょり実現性の強い検 討がなされてきた。

スイス $\mathrm{BBC}$ 社7) は現在の技術でほぼ可能と思われ る MHD〜火力組合せプラントを提唱している。すな わち発電通路, 熱交換器にはすべて金属を使用し, シ 一ド物質である $\mathrm{K}_{2} \mathrm{SO}_{4}$ の融点以下に表面温度を保つ ことを考えている。このため総じて温度はあまり高く

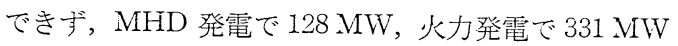
の出力を得, 総合効率は 45.9\% となつている。この 方式の一つの特徵注現在一つの問題となつている熱交 
換器とシード回収の問題をガス温度をあまり上げずに らまく解決していることにある。

米国の WH 社 ${ }^{8)}$ は予熱空気の石油燃焼ガスにセシ ウム原鉱をシードした作動ガスを用いるプラントにつ いて 200 種類以上の組合せにつき検討した結果, 現在 の技術で最高と思われる例を示している。燃料の石炭 は乾留器によつてガス化され, まず燃焼器の前段でコ 一クスを燃焼させ後段で石炭ガスの燃燒を行なわせ る。この場合は MHD 発電部で $394 \mathrm{MW}$, 火力発電 部で $399 \mathrm{MW}$ の出力を得て総合効率は $50.4 \%$ であ る。乾留によつて得たコークスのみを用いるときは, 総合効率が少し上り約 $52 \%$ となる。

2) 開発計画および現状

米国 AVCO 社法これまでどおり，大型発電機の開 発実験において群を抜いている。まず MARK II に よる $1,500 \mathrm{~kW}$ 発電に成功し, MARK $\mathrm{V}$ を用い 26 MW の発電に成功した。また1969年までに $30 \mathrm{MW}$ ， 1ケ月運転の計画を発表している。

イギリスの中央電力聍は MHD 発電プラントの 開発に巨額な投資を行ない，20 MW のプラントを Marchwood Engg. Lab.に建設中である。これは1969 年までに 1 時間運転の実験を行ない，それ以後同出力 で1ケ月に運転時間をのぼす計画である。

フランスに㧍いては電力公社が中心になつて $50 \mathrm{~kW}$ の小出力発電機を用いて, 主として材料の開発を目的 とした10時間運転実験を行なつている。

ソ連における MHD 発電の研究はこれまであまり 知られていなかつたが, 前述したように大量の論文発 表がなされ, 注目を集めた。内容は MHD 発電のあ らゆる分野にわたつており，基礎的なしかし着実な研 究がなされている。

わが国においては，引き続き大型プロジェクトの一 環として電気試験所に $1 \mathrm{MW}$ の発電機が建設され, 実験が行なわれている。実用 MHD 発電機は大容量, 長時間運転に適し，かつ信頼度の高いことが要求され るので，実験もこの線に沿つてなされなくてはならな い。現在行なわれている方法は短時間ではあるが大出 力の装置で主として寸度効果を実験し, 小出力の装置 で長時間運転の実績を得, この双方から大出力, 長時 間運転の資料を得ようとするものである。電気試験所 における実験計画もほぼこれと同様な方針で，上記の $1 \mathrm{MW}$ 発電機で数分の運転試験を行ない，別に 10 $\mathrm{kW}$ 程度の小出力長時間運転用の発電機を建設中で ある。

3）熱交換器およびシード回収
MHD 発電を商用化することにおける一つの問題は 熱交換器㐨よびシード回收技術であり, 各国で研究が なされている。MND 発電の熱交換器はシード物質に よる侵蝕を受けるので，その点従来の技術を基礎に種 タの新しい方策を取らなくてはならない。先述した $\mathrm{BC}$ 社の方式はシード回収をもかねた熱交換器として 注目される。イギリスの中央電力庁 ${ }^{9)}$ で注蓄熱式, ス ラグ式，サブシステム式などの形式について検討をす すめている。スラグ式は $\mathrm{K}_{2} \mathrm{SO}_{4}$ などを熱担体として 用い，上の加熱室を粉状で落下しながら燃燒排ガスで 融解され，下の室でこれを噴霧落下させ，燃燒用空気 と熱交換させるもので，融解の潜熱を利用した熱交換 器である。この方式はシード物質による熱担体の侵蝕 が問題にならない利点をもつている。サブシステムは 燃焼用空気を不純物の少ない LNG などを燃料とする 別置然焼器を用いて予熱するもので, シード物質によ る侵蝕がない上に，熱交換器の管内外圧力を等しくす れば，セラミック管などを用い，かなり高温の予熱ガ スを得ることができるなど，多くの長所が考えられ る。米国 AVCO 社10)ではペブルベッドの熱交換器を 用い，熱交換器のシード物質による目詰りの実験を報 告している。シード回収技術を開発するに際し，その 基礎資料としてシード物質の蒸気圧曲線が必要となる が，イギリス中央電力庁 ${ }^{11} や \mathrm{AVCO}$ 社でこれらの実 験データを発表している。

\section{4）流路構造および材料}

発電部の流路構造についてはこれまで主として角型 断面の Faraday 型および Hall 型のもの, あるいは Disc 型のものが実験されていたが，AVCO 社 ${ }^{12)}$ は MARK II の燃焼器を用いて円型断面の Hall 型 発電実験を行なつた。また Dicks ${ }^{12}$ らは Hall 型の変 形と考えられる Diagnal 型についての理論研究およ び実験を行なつている。電極および絶縁壁の構造につ いてはこれまで冷却を行なわない hot wall あるいは 水冷を行なう cold wall が主として行なわれていた が，水冷銅製あるいはステンレス製の金属冷却部分に セラミックスをコーティングした semi-hot wall の 研究がなされ，これと同時に材料の開発 ${ }^{14)}$ 盛んに行 なわれている。

\section{5) 電磁石}

MHD 発電に必要な機器のうちで電磁石の占める位 置は大きい。超電導コイルは他の低温コイル $(\mathrm{Na}$, $\mathrm{Al} ， \mathrm{Cu}$ などのコイルを液体水素や液体窒素温度で用 いる) や常温の銅コイルに比して $5 \mathrm{web} / \mathrm{m}^{2}$ 以上の強 磁界の発生に対して, 設備費, 維持費などを検討する 
と最も経済的といわれている ${ }^{15)}$ 。超電導線を用いた大 型強磁界装置が最近 AVCO 社 ${ }^{16)}$ とより運転されたこ とはこの点意義深い。

\section{2. 密閉サイクル}

密閉サイクル MHD 発電の経済性について Booth 17) は原子力発電と組合せた商用プラントについて検討 し，MHD 発電との組合せが他の発電方法との組合せ に比して最も有利であると述べている。密閉サイクル に用いる作動流体について, McNary ら ${ }^{18)}$ にる $\mathrm{He}$, $\mathrm{Ar}, \mathrm{Ne}$ などについての検討から, 原子力 $\mathrm{MHD}$ ブ レクトンサイクルを考える場合には $\mathrm{Ne}-\mathrm{Cs}$ の組合せ がよいと述べている。一方 Rice ら ${ }^{197}$ は高圧の原子炉 の場合には Ar が有利になると述べている。非平衡電 離ガスの諸性質に関する研究も盛んで, エネルギーバ ランスからこれを求めようとするものなどが20221) 発表 された。

発電流路内に扝ける電流, 電圧分布については,

Celinski と Fischer ${ }^{22)}$ による数值計算がある。

誘起電界による非平衡電離を利用した発電機では Hall 電圧が予想值を下まわる現象があり, Kerrebro$\mathrm{ck}^{23)}$ により，電極壁面にそう Tovle 加熱の強い層が 現われることが原因であるとの解採がなされた。発電 流路内での電流分布についての実験では Fischer ${ }^{24)} の$ カリウム共鳴線の強度分布を利用した測定があり，気 流の影響で電流が下流に拡がり，見かけの内部抵抗が 增加する現象を見出した。電極壁に沿う電位分布の 測定を行ない，䧔極側で，相隣れる電極間でかなりの Hall 雪流がショートしており，これが，この種の非 平衡電離発電実験を不成功にしている一原因と考えら れている。

発電実験については AVCO 社 ${ }^{25)} の$ 直線型発電チ ヤネルおよびDisc を用いた実験があり，不安定性に ついての種々の問題が諭ぜられている。イギリスの $\mathrm{IRD}^{26)}$ では小型ではあるが，本格的な密閉少イクル の実験を行なつており, 密閉サイクルで問題となる作 動流体の循環淨化，シード回収などの連続運転実績を 上げている。しかし，この装置はチャネル寸法が小さ いため, 確実な非平衡電離が観測されているとはいえ ない。このようなサイクル実験は機器の数が多くなる ため，大きなチャネルによる実験を行なうことがむゔ

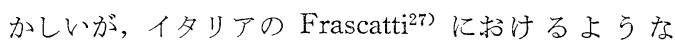
Blow down 形式の大型実験が行なわれ，好ましい結 果が得られている。この他米国 $\mathrm{GM}^{28)}$ ，フロリダ大 学 ${ }^{29)}$, 西独 ITP ${ }^{80)}$ の ARGAS と称する大型実験機 などがある。
3. 液体金属サイクル

液体金属サイクルで問題となる液体金属の加速法お よび二層流の導電度などについての研究が主として行 なわれた。発管チャネル内を流れる二層流にはボイド が存在するが,このボイド率が導電度におよぼす影響 について Petrick ${ }^{21)} の$ 低速の水 空気および高速の $\mathrm{NaK} \sim \mathrm{N}_{2}$ による実験がある。前者は Maxwell の理 論式に合うが，後者はその低下率が大きい上述べてい る。一方, Kirillov ${ }^{32)}$ の $\mathrm{Na}$ ループの実験によれば, 噴霧流の領域で Maxwell の式によるよりも高い導電 度が得られ, 液膜表面からの電子放射によるものと説 明している。

能率よく液体金属を加速するには，均一な二相流を 作ることが必要で，その一方法として液体る数段に分 けて除々に加える方法 ${ }^{33}$ などが提案された。

液体金属サイクルは，液体加速機，ディフューザ， 気流分離機などの効率に不明な点が多く, サイクル効 率などについての検討をすることが現段階で注むず

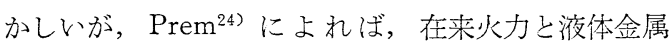
MHD サイクルとの組合せで，総合効率 $51 \%$ が得ら れると述べている。

2. 熱電気, 熱電子発電

この種の発電のあらましについては本誌の昨年度の 報文で述べたが，構造が簡単，可動部分がないこと， 環境に適用性があること，放射性物質をエネルギ減に 用い得るこことなどを特徴としており，長期間の使用 に向いている25)ため，各国で宇宙用，極地用，あるい は海底用, 海面ブイ用電源として開発されまた利用さ れている。特に宇宙用電源として原子力推進の場合に は水または液体金属を作動流体とする回転発電機ラン キンサイクルと単一ループの熱電気発電の組合せおよ び回転発電機ブレイトンサイクルと単一ループの熱電 気発電の組合せなど36)が考光られている。

理諭的研究としては, 熱電機発電の始動に際しての 過渡状態について，発電素子内の温度分布を時間およ び場所の函数として解き, 出力電流を時間の函数とし て解いたもの 27728)がある。この他, 理論的, 実験的研 究が本年度東京で開かれた World Power Conference で数多く発表された。

\section{文献}

1）森, 日本機械学会誌 70 (576), 19 (1967)

2）たとえば41年度電気学会東京支部大会前刷集 (昭和41.11) 「会誌 8，(3)，141

3) 原子力直接発電研究專門委員会, 日本原子力学

4) 森, 超高温研究 3, (4), 166

5）森，動力， 91，24 
6）玉置，荻原，機械の研究，18 5, 591

7) M. Rosner, Symp. MHD, SM-74/28 (1966)

8) T. C. Tsu, W. E. Yonng, S. Way, Symp. MHD, SM-74/179 (1966)

9) British MHD, Collaborative Research Committee, Symp. MHD, SM-74/43 (1966)

10) F. Hals, Symp. MHD SM-74/68 (1966)

11) C. E. G. B., Symp. MHD, SM-74/43 (1966)

12) J. Teus, T. R. Brogan, Symp. MHD, SM $-74 / 50$ (1966)

13) J. B. Dicks, Y. L. Wu., R. E. Ziemer, W. L. Powers, R. V. Shanklin, III. Symp. MHD SM-74/169 (1966)

14) A. M. Anthony, M. Foex, Symp. MHD, SM-74/67 (1966)

15) K. Reichert, E.T.Z., A87, H4, 132 (1966)

16) Z. J. J. Stekly, Int Inst. Refreg., Commission I, VI-1, (1966)

17) L. A. Booth, Trans. ASME, Series A, 88 4, 345

18) C. A. McNary, W. D. Jockson, Symp. MHD, SM-74/161 (1966)

19) G. Rice, M. J. Porsons, Symp. MHD. SM $-74 / 251$ (1966)

$\lceil-74 / 47(1966)$

20) M. Stühle, H. Borkhardt, Symp. MHD, SM

21) J. F. Shaw, C. H. Kruger, M. Mitchner, J. R. Viegas, Symp. MHD, SM-74/176 (1966)

Г4 3421

22) Z. N. Celinski, F. W. Fischer, AIAAJ.,

23) J. L. Kerrebrock, $A I A A J, 4$ 11, 1938

24) F. W. Fischer, Symp. MHD, SM-74/20 (1966)

25) J. Klepeis, R. J. Rosa, 7 th Symp. Eng. Asp. MHD (1966)

26) R. Brown, B. C. Lindley, I. R. McNab, Symp. MHD, SM-74/36 (1966)

27) E. Bertolini, R. Tosihi, B. C. Lindley, R. Brown, I. R. McNab, Symp. MHD, SM$74 / 24$ (1966)

28) T. L. Rosebrock, D. L. Topton, D. L. Clingman, R. L. Koch, R. O. Whitakev, Symp. MHD, SM-74/181 (1966)

29) R. T. Schneider, H. E. Wilhelm, Symp. MHD, SM-74/160 (1966)

30) Th. Bolm, S. Förster, G. Kolb, C. Holzapfel, G. Noack, Symp. MHD, SM-74/124 (1966)

31) M. Petrick, Symp. MHD, SM-74/196 (1966)

32) P. L. Kirillov, V. I. Subfotin, I. P. Stakhanov, M. M. Turchin, Symp. MHD, SM $-74 / 106$ (1966)

33) R. Radebold, H. Lang, T. Schulz, H. Weh, E. Klein, K. H. Wagner, Symp. MHD, SM-74/30 (1966) Г(1966)

34) L. L. Prem, Symp. MHD, SM-74-184

35) R. D. Bennett, Astronautics \& Aeronautics,
June. 72 (1966)

36) J. Grey, ibid., March, 68 (1966)

37) D. Tai-Ko Shaw, Nuclear Science \& Eng. 243,227 「6 (1), 57 (1966)

38) D. Tai-Ko Shaw, Advanced Energy Conv.

注）文献中 Symp. MHD. は 1966年7月 Salzburg で開催された International Symposium on Magnetohydrodynamic Electrical Power Generation の略である。

\section{3 地熱発電の動向}

わが国における地熱発電の歷史は古くかつ新しい。 正正 8 年には海軍中将山内万寿治氏が全国を踏査し, 九州別府において $25 \mathrm{~m}$ のボーリングを行ない蒸気の 噴出をみたという記録がある。

その後, 大正14年, 東京電灯の研究所長太刀川平治 氏が上記の蒸気を利用して $2 \mathrm{~kW}$ の発電をしたのを皮 切りに，それ以来 $10 \mathrm{~kW}$ ないし $30 \mathrm{~kW}$ 程度のきわ めて小規模な発電は試みられたものの商業規模の地熱 発電を行ならことができず，ある時期においては，わ が国における地熱発電はもはや絶望的であるとさえ思 い込まれたものである。

ところが, 最近, 岩手県松川地区で 2 万W の地熱 発電所が完成し順調に電力を生産し始めると, ようや く地熱に対する各方面の認識が変わり始めたようで， 近くは九州電力が大分県下で 1 万 $\mathrm{kW}$ の発電を行な べくその建設を進めているし, 電源開発は宮城県鬼頭 地区で, 杤木県では那須地区で，北海道開発庁および 北海道庁では鹿部地区でそれぞれ開発の調査学進めて いるといつた情況で，日本にもよらやく地熱開発のブ 一ムが，静かではあるが到来しつつあるように見受け られる。この際, 過去を振り返りつつ, 世界的な観点 から地熱発電の動向を展望してみたい。

\section{I . 世界の事情}

世界において最も古くから地熱発電が行なわれてお り，かつ現在最大の規模を誇るのはイタリーである。

大正 2 年といえば，わが国で始めて $2 \mathrm{~kW}$ の地熱発 電を行なつたという大正 14 年よりさかの隹ること 12 年 前であるが，イタリーでは早くも250 kW の電力を生 産し，電灯照明などにこれを利用していた。以来，そ の規模を㹡大し第二次大戦中すでに 14 万W となつ ていたが，戦災を受けて一時罱滅状態に陥入つた。だ が，戦後ただちに復旧，現在では 35 万W の設備容 量を有し，世界第一の規模を誘つており，かつ，第二 次大戦前から地熱発電を行なつていた世界唯一の国で ある。 
第二次大戦後、イタリーについで地熱発電を行なつ たのはニュージーランドであり，現在 19 万 $\mathrm{kW}$ の設倫 容量を有し世界第二位である。その他，ソ連（カムチ 中ッカ半島) の 3 万 $\mathrm{kW}$, 米国 (西海岸) 2.8 万 $\mathrm{kW}$, メキシコの 1 万kW，などがあるが，いずれも第二次 大戦後開発したものばか门であるから，世界的にみる と地熱発電はまだその草創期を脱しているとはみられ ない。日本も，このところ，2 万kW の地熱発電所を 完成したのであるから，こうした戦後派の一員に最近 加わつたわけであり，その規模の大きさからいえばイ タリー、ニュージーランド，ソ連，米国についてで第 五位に入る。

話は若干古くはなるが，昭和36年，国連主催の新エ ネルギ会議が開かれ，太陽エネルギ，風力とともに地 熱エネルギが会議の主題に選ばれ，関係各国の専門家 が集まつて論議が操り展げられた。もちろん，その 䟢，日本からも何人かの息門家が参加し論文の発表な ぞを行なつたが，残念ながら当時まだ日本では地熱発 電が行なわれておらず，妇つ弪ら世界事情孝吸收する のに主力が注がれたようである。だが，もし，日本に おいて 2 万 $\mathrm{kW}$ の発電に成功している今日の立場にお いてこの種の国際会議が開かれていたら事情はもつと 変わつたものになつていただろう。

昨年夏, 東京で第11回太平洋学術会議が外人学者ら 2,000 人を集好開かれたことは御承知のとおりであ る。その際, 米国, 英国, カナダ, ソ連, インド，イ ンドネシアなどからも30数編の地熱関係論文が提出さ れ，かつ，会議後の見学旅行にて松川地熱発電所が選 ばれたが，まだその完成以前であるというのに早くも 数十名の外人学者が現地の見学旅行に参加している。

それはさておき, 日本の松川地熱発電所の成否は, 日本よりはむしろ海外から強い関心が寄せられていた ようである。というの洁，アジア地域において地熱発 電をものにした国がまだかつてなかつたことから，日 本における地熱発電の成否は, アジア地域におけるそ の可能性を占うものとして，劣るいは，地球的な角度 からする貴重な学術情報を提供するものとして注目さ れていたからである。

こうした訳で，日本の「地熱発電成る」の情報注松 川発電所の完成と同時に世界各国にも流れた。

フランスや西独から，あるいは国連からも問合せが 飛び込んできた。数年前から地熱の調查をはじめてい たフィリッピンからは専門家のほかに科学開発庁の次 官までが来日した。そして国連からも倸官が派遣され てくるといつた類で, 松川発電所の外国人見学者はそ
の後も跡を絶たない有様となつた（国連は，その特別 基金から低開発国における地熱の調查研究を援助する ため，トルコ，チリ，エルサルバドルにそれぞれ数百 万ドルづつ出している)。

地熱発電は欧米諸外国においての及可能であり，ア ジアで洨不可能であるうとアジア人がそれ之なく愣い ていた先入観は, 松川発電所の完成を機にようやく払 拭されたようである。

かねてから研究を進めていた台湾やフィリッピンで もこのところ急にその調查に本騕が入つたきた之聞く が，これもその一つの現われであろう。

では，一体，地熱発電に対しこのような強い関心を 集めるに到つた所以はなんであるうか。以下，その問 題に触れてみたい。

\section{II. 経済性その他の得失}

地熱発雪の魅力泣何といつてもその発電コストの低 篻なことである。

地下から自然に噴出する蒸気をタービンに加えさえ すれば電気起るのであるから，火力発電の場合のよう に高い煙突を立て六り大きなボイラーを据付け，発電 コストの大きな部分を占好る石油や石炭を焚く必要が ないからである。

米国の地質学者 D. E. White 氏の報告によると， イタリーの地熱発電コストは $1 \mathrm{kWhr}$ 当り 0.86 円〜 1.03円，ニュージーランドのそ机は 1.4 円，米国のそ れ注約 1.6 円だという。まことに驚異的な安さであ る。

それに，その年閤稼衝率の高いことも電力関係者か らみると大きな魅力の一つとなる。燃料营は只である から定期検查などで発電機を停为る場合以外全負荷で 運転することができるからで，ベース・ロード用発電 所としてもつてこいなのだ。（イタリーの場合，その 年間稼働率はほとんど $90 \%$ 近くである。)

さらに，地熱発電の場合，大量の熱湯が放出され温 泉源や暖房源などとして利用されるのも，温泉愛好者 の多い日本などでは歓迎さるところである。アイスラ ンドでは工場用熱源, 都市のセントラル・ヒーティン グなどに大量の熱湯を利用しているが，これなども変 わつた利用の仕方といえよう。

こうした好ましい面がある反面，困つた問題がない わけではない。

たとえば，地下蒸気の中には望ましくないいろいろ の化学成分が含まれていることがある。金属定腐蝕さ せたり，スケールの付着する因となる成分交大つてい たりする。今日の技術では，こうした難問題も一応克 
服されるとはいえ，いろいろ問題が残される。

イタリーの地熱発電所では, むしろ積極的に蒸気中 の化学成分を抽出し工業生産を行なつているが，これ などは禍を転じて福となしている例である。蒸気の中 から硼酸をとつたりアンモニヤを作つて販売している のである。

まだ，その他にもいろいろ問題があるが，一番問題 なのは蒸気并の寿命である。

折角多額の費用を投入して堀り当てた丞気井も途中 でその勢力が隇衰したり止まつたりしては大変なので ある。

蒸気井の勢力が減袁する原因としてまづ考えられる のは, 井戸の内部にスケールが付着してその勢力を弱 めること。もら一つは土地の崩壞などで井戸がつまつ てしまうことである。いずれも，今日，そらした原因 による勢力の減衰はこれを回復させる方法があるの で，これら特に大して問題とするには当らないが， 地下蒸気発生の根源であるマグマ溜の熱量そのものが 予想外に小さかつたりすると致命的な問題となる。

しかし，も550年以上もの歴史をもつイタリ一の場 会でも，第二次大戦後開発したニュージーランド，あ るいは米国の場合にしても，一本一本の蒸気井につい ていらとスケールや土地崩壊などのため蒸気の勢力が 弱まる井戸があつても，多数の井戸で地域全体から取 り出せるエネルギー総量は実績として増加しており減 少していないのである。このことは地下のマググマ溜 りの熱量がきわ的て大きなものであることを逆に示し ているようだ。

マググマ溜りというのは，地下の割れ目などに沿つ てマグマが地表面下かなり浅いところに浮上浸入して できる熱の塊りと䓔えられている。これが地下水を溜 め, 地熱発電用の蒸気を涵養するものであるが, 例示 ではあるが，その保有している熱量を石炭換算で表わ すと，

$\begin{array}{lr}\text { Salton Sea (米国) } & 30 \text { 億 } \mathrm{t} \\ \text { Steamboat Springs (米国) } & 2 " \prime \\ \text { Wairakei (N. Z.) } & 4 " \\ \text { Iceland } & 15 "\end{array}$

といつた類で，その巨大さが類推されよう。もし，こ らしたマグマ溜りの持つ熱源によつてその地域の地熱 蒸気が涵盖されているとしたら, 地熱発電所の寿命は 半永久的もものとさえ考えられるのである。

\section{III. ま と め}

冒頭に「わが国における地熱発電の歷史は古くかつ 新しい」と述べたが，このことは世界を通じてもいえ
そうだ。

地熱発電が従来の水力や火力に比しはるかに有利な 発電方式であるという見透しは古くから立てられてい たが，地上から確実に地下の蒸気源を探し当てる技術 が確立されていなかつたために長い間の暗中模索が続 いたのである。

失敗の操返しによる経験の蓄積と, 近年における科 学技術の飛躍的発展は地球科学の前進と相まつて, 最 近ようやく前記の長い期間にわたる暗中模索を打破し 得るに到つたものとみられる。

宇宙時代の到来で人類の目が大空にひきつけられて いるかにみえる今日，実はその足許を今さらのように 見直すときが近づきつつあるのである。

昭和32年から始まつた国際地球観測年には，日本は もちろん世界中の60数ケ国が参加し，地球を中心とす るあら河る角度からの調查が行なわれたが，その結果 はそれまで知られていなかつた地球内部の事情を一層 明らかにするとともに，地熱の源泉が何にあるかとい ら点に関し有力な手掛りを提供してくれた。また，そ の保有熱量なるものが予想をはるかに越えて巨大であ ることが次第に明らかになるとともに放射能物質の放 壊に伴なら熱の発生とその蓄積という新しい考え方が 次第に支持されるようになつたのである。

そして,こうした考え方の変化は地熱開発への関心 をますます高からしめる方向にプラスしたのである。 国連が新エネルギ会議を開いたり，特別基金から援助 資金を出して低開発国の地熱開発を援助するようにな つたのもこうした地球に対寸る認識の変化に基づくも のであるらと考觉られる。

エネルギ問題の解決に一つの明るい夢を提供するも のとして，今後地熱の開発は世界的な注目を浴びっっ 前進の速度を次第に高めてゆくのではないだろうか。

\section{4 燃料電池の動向}

1966年には, 燃料電池の開発あるいは研究について 画期的な進歩汸られなかつたが，世界における然料 電池に対する関心は依然としておとろえをみせず，国 際会議も活発で，1966年 9 月イギリスのブライトンで 開かれた第 5 回国際動力源シンポジウムおよび東京で 開催された第17回国際電気化学会議などで燃料電池に 関する報告が多数提出され，特に京都でおこなわれた 燃料電池討論部会では, 米, 仏および日の研究者によ つて話題が提供され，ソ連の研究者とともに真剣な討 諭がかわされた。また，1967年 3 月に東独のドレスデ 
ンで，6月にベルギーのブリュッセルでそれぞれ国際 然料会議が開かれることになつている。

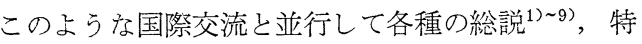

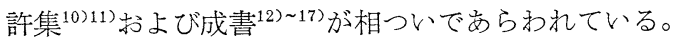

なお，燃粼電池開発の方向としては，炭化水素一空 気系の電池に主力がむけられつつある傾向がみられ， 民需用然料電池の実現の方向が示されてきている。

\section{I . 水素酸素燃料電池}

多くの湯合に, 各種燃料を最終的に水素に変性して 電池を作動させる方法が考えられるので，この形式の 電池の開発および研究は多い。アメリカにおいて宇宙 開発用之して実用されているのはこの新のもので, 1966年に終了したジェミニ計画では GE 社の $1 \mathrm{~kW}$ イオン交珤膜電池 2 ケを衛星船につんでいたが，この 電池汒 $0.6 \mathrm{~kW} / \mathrm{ft}^{3} ， 15.5 \mathrm{~W} / \mathrm{lb}$ の特性を示し ${ }^{18)}, 1968$ ～1972年には $2 \mathrm{~kW} / \mathrm{ft}^{3} ， 35 \mathrm{~W} / \mathrm{lb}$ の性能が期待され

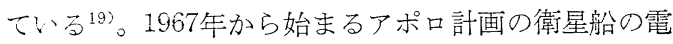
源は PWA 社の $2 \mathrm{~kW}$ のベーコン型電池で, 温度 $200 \sim 250^{\circ} \mathrm{C}$, 方压 $3 \sim 4$ 気圧, 電解液 $80 \% \mathrm{KOH}$, アノート $\mathrm{Ni}$ ，カソード $\mathrm{NiO}$ で $250 \mathrm{~mA} / \mathrm{cm}^{2}$ 熱効率 65\% で作動させるもの ${ }^{4)}$ で，衛星船にはこれを 3 ケ 塔载する。また， $\mathrm{AC}$ 社では，アスベスト毛管膜電池 を $\mathrm{Pt}-\mathrm{Pd}$ 触媒, $80^{\circ} \mathrm{C}$ で作動さす, $3 \mathrm{~kW} / \mathrm{ft}^{3}, 30 \mathrm{~W} / \mathrm{lb}$ の出力密度をえ ${ }^{20)}, 26 \mathrm{~V}, 200 \mathrm{~W}$ の電池をタイタン III-C ロケットに積み込んで試験している ${ }^{21) 。 こ の よ ~}$ うな宇贯荓発用然料電池は 3,000 5, 000 ドル/lb であ るといわれている4からここのまでは民需用として 問題にならないが，触媒として白金の代わりにほう化

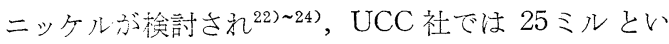
ら薄い炭美電極を用いて $16 \mathrm{~W} / 1 \mathrm{~b}, 30 \mathrm{~kW}$ の電池を 開発 ${ }^{25}$ しているがGM社ではこの電池を自動車の動力 用として梌討している ${ }^{26)}$ 。また， $\mathrm{S}$ 社では 4 5 人乗 りの電気ボートの動力源として $24 \mathrm{~V}$ の $\mathrm{H}_{2}-\mathrm{O}_{2}$ 燃料 電池を用いて $7 \mathrm{~km} / \mathrm{hr}$ の速度をえている26)。また， スエーデンでも $1 \mathrm{t}$ フォークリフト， $2 \mathrm{t}$ 積みトラッ クおよで電気機関車が, ニッケル黒アノード, 銀カソ ードで検討され27)ているが，走行距離に問題があり， たとえ惊上記のトラックの場合 $70 \mathrm{~km} / \mathrm{hr}$ の速度で 1 時間が限度である。

このような電池の寿命試験は各所で行なわれ，たと えば炭素電極, $30 \% \mathrm{KOH}$ で $50 \mathrm{~mA} / \mathrm{cm}^{2}, 100 \mathrm{~mA} /$ $\mathrm{cm}^{2}$ などで 10,000 時間以上の試験が行なわれてい る $^{23)}$ 。

なお，隔膜を使用し，多孔性電極からガスを吹き出 す方式で $80^{\circ} \mathrm{C} ， 50 \sim 100 \mathrm{~mA} / \mathrm{cm}^{2}$ の性能の電池がえ
られ29)， Pd-Ag 合金薄膜をアノードに使用する方式 も検討されている ${ }^{30)}$ 。

\section{III.アンモニアおよびヒドラジン空気燃料電池}

アンモニアは水素源と考えられ，アンモニアクラッ

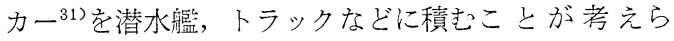

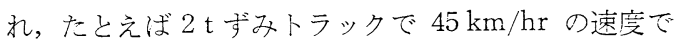
$900 \mathrm{~km}$ の走行距離がえられるという27。

また，常温で液体のヒドラジンを燃料とする電池 が高性能電池さして注目され，たこえば M 社では $5 \mathrm{MKOH}$ に0.5 $3 \mathrm{M}$ の $\mathrm{N}_{2} \mathrm{H}_{4}$ 索溶解し, $\mathrm{Pd}$ 触媒

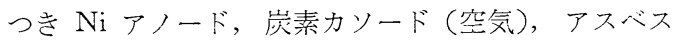
卜隔膜孛用いた $70^{\circ} \mathrm{C}$ で $60 \mathrm{~W}$ のレーダー電源少よび $300 \mathrm{~W}$ の軍用電源を誈作している32)。また，28 V, $5 \mathrm{~kW}$ の電源が試作され ${ }^{332}$ ，さらに $40 \mathrm{~kW}$ の電源が 設計中であるという。

\section{III. メタノール空気燃料電池}

メタノールを電解液に溶解させる直接法ではアルカ リ性電解液を用いるもの上酸性電解液を用いるもの上 がある。前者の例として $5 \mathrm{MCH}_{3} \mathrm{OH}-6 \mathrm{MKOH} の$ 電解液, $\mathrm{Ni}$ アノード, Ag 触媒カソード, Permion 300,320 隔膜で $3,000 \mathrm{hr}$ の試験に成功している また，スイスで $20 \mathrm{~W}$ のメタノール空気然料電池がテ レビのリレーステーションの電源として使用され ${ }^{35)}$, ドイツで $60 \mathrm{~W}$ の電池がブイの電源に使われている。 この場合, メタノール十電解液 400 l で $180 \mathrm{kWhr} の$ 電力がえられるといら13)36)。

このようなアルカリ性電解液の電池では放電生成物 が電解液中に蓄積するからこの再生が必要であるが， 酸性電解液を用いればこの点が改良される期待がある ので硫酸電解液で研究されている。たとえば， E社で は $3.7 \mathrm{MH}_{2} \mathrm{SO}_{4}, 0.75 \mathrm{M}$ メタノールで $80 \mathrm{~mA} / \mathrm{cm}^{2}$, $132 \mathrm{~W}$ の電源を試験し ${ }^{37)}$ ，生成する水を除去する適正 速度を検討している ${ }^{38)}$ 。

なお, メタノールの酸化生成物のギ酸塩は固体で取 扱いが容易であるところから，これを燃料とする電池 が検討され， $4 \mathrm{M} \mathrm{KOH}$ または $\mathrm{K}_{2} \mathrm{CO}_{3}$ 中に $4 \mathrm{M}$ の ぎ酸カリを溶解して $90^{\circ} \mathrm{C}$ で $200 \mathrm{~mA} / \mathrm{cm}^{2}$ の電流密 度がそれぞれ $0.82 \mathrm{~V}$ および $0.5 \mathrm{~V}$ (ただし電池の内 部抵抗で降下する電圧を含まず) でえられている ${ }^{39)} 。$

また, あらかじめ変性器でメタノールを水素に変性 してから電池をはたらかせる間接法 ${ }^{40)}$ では, 変性器を 電池の外に設ける外部変性法と, 電池内で変性する内 部変性法が考えられ，前者の例では，メ夕ノール上水 との混合物を $300^{\circ} \mathrm{C}$ で $\mathrm{H}_{2}+\mathrm{CO}$ にし, $\mathrm{Pd}-\mathrm{Ag}$ 膜で 水素のみをとり出し, $5 \mathrm{NKOH}$ 電解液の $6 \mathrm{~kW}$ の電 
電池を $80^{\circ} \mathrm{C}$ で作動させ, 変性器も含めて $97 \mathrm{lb} / \mathrm{kW}$, $1.1 \mathrm{ft}^{3} / \mathrm{kW}$ で $40 \%$ 熱効率をえ，後者の例では， $75 \%$ $\mathrm{Pd}-25 \% \mathrm{Ag}$ をアノード, $85 \% \mathrm{KOH}$ を電解液とし, メタノールと水との混合物をアノード室に送入し, $225^{\circ} \mathrm{C}$ で, $80 \mathrm{lb} / \mathrm{kW}, \quad 0.57 \mathrm{ft}^{3} / \mathrm{kW}$ の性能を熱効率 $50 \%$ でえている ${ }^{41}$ 。

\section{IV. 炭化水素空気燃料電池}

核燃料をのぞけば，すべての燃料中で最もエネルギ 一密度の高、燃料である炭化水素は, 広、範園にわた つて燃料電池いの適用が検討されている。この場合 も,メタノールと同様に直接法と間接法とがある。

直接法はすべて酸性電解液が用いられ ${ }^{42)}$, たとえば, $110^{\circ} \mathrm{C}$ で $26 \mathrm{~N}$ リン酸, $90^{\circ} \mathrm{C}$ で $3 \mathrm{~N}$ 硫酸を電解液と しラネー白金を触媒とする金電極で，メタン，エタ ン，ブロパンおよびブタンを燃料とする場合が検討さ れ, 硫酸電解液を用いたほらが高電流密度をうること が認められ ${ }^{42)}$, 特に, ブロパンーリン酸系の場合につ いて, 触媒として Pt, Pd, Rh および Ir などが検討 され，Ptが最もすぐれていることが認められた ${ }^{44)}$ また，テフロンでかためた白金黒電極 ${ }^{45}$ ， ホウ化ニッ ケル触媒 ${ }^{46)}$ あるい注手触媒の担体として炭素あるい

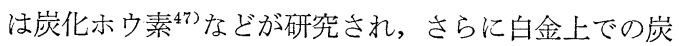
化水素の酸化反応の機作が研究されている ${ }^{48) ~ 51) 。 な ~}$ お, 弗化物系の電解液が推奖され, $\mathrm{CsF}-\mathrm{HF}-\mathrm{H}_{2} \mathrm{O}$ 系 $\left(\mathrm{H}_{2} \mathrm{O} 12 \sim 15\right.$ モル $\left.\%, \mathrm{HF} / \mathrm{CsF}=2.0 \sim 3.0\right)$ の電解液 で, 白金触媒, $70 \sim 150^{\circ} \mathrm{C}$, プロパン一酸素電池につい て $200 \mathrm{~mA} / \mathrm{cm}^{2}, \mathrm{HF}-\mathrm{H}_{2} \mathrm{O}$ 系 (37 $\mathrm{mol} \% \mathrm{HF}$ ) 電解 液で, $105^{\circ} \mathrm{C}$, プロパン-酸素電池につき $130 \mathrm{~mA} / \mathrm{cm}^{2}$ の電流密度がえられている52)。電池はテフロンで主要 部分がつくられている。

このような直接法は, 液体炭化水素を燃料とする場 合は不便が多いので，このような燃料については関接 法が採用される。その方法としては, 変性器で水素に 変性する方法, 部分酸化あるいは熱分解して活性化ガ スをえる方法などがとられる。

変性する場合は,メタノールの間接法の場合と同様 に，外部法と内部法とがある。

外部変性法では常温然料電池をはたらかせることが できるが，リホーマーには $800 \sim 450^{\circ} \mathrm{C}$ 程度のものを 用い, メタン ${ }^{53)}$, ガソリン, ヘキサン, $\mathrm{JP}-4^{54)}$, JP-1255) あるいは JP-150 56)57) などを水蒸気変性し て $\mathrm{H}_{2}, \mathrm{CO}$ および $\mathrm{CO}_{2}$ にかえ，そのまま酸性電解 液が陽イオン交換膜電池へ導入して電池を作動させる ${ }^{58)}$ か，または $\mathrm{CO}_{2}$ 除去器に $\mathrm{Pd}-\mathrm{Ag}$ 合金膜を用い59 水素のみにしてアルカリ性電解液電池をはたらかせる
55) 57)方法が考えられ, 後者の方法で $5 \mathrm{~kW}$ の電源装

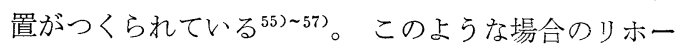
マーの触媒としてはイオウに被毒され難いものを使用 するかまたは触媒のカートリッジを考えるべきだとい われている60)。しかし, 可搬型の場合はもちろんのこ とリホーマーが別にあることは不便が多いので内部変 性法が考えられるのであつて, $\mathrm{Pd}-\mathrm{Ag}$ 合金膜アノー ド, $85 \% \mathrm{KOH}$ 電解液の電池が $200 \sim 250^{\circ} \mathrm{C}$ で, メ タン、ヘキサンあるいはガンリンを燃料として内部変 性法で作動され高性能がえられている ${ }^{61)}$ 。

また, 液体炭化水素の空気による部分酸化によつて えられる $\mathrm{H}_{2}, \mathrm{CO}, \mathrm{CH}_{4}$ を使用して溶融炭酸塩を電 解質とする高温然料電池を $650^{\circ} \mathrm{C}$ で作動させる方法 が考えられ，30 W/ $\mathrm{ft}^{2}$ の出力密度で $3 \sim 10 \mathrm{~kW}$ の電 池が検討されている62)。

このように高温燃料電池をはたらかせる意味は不純 な水素でも効率よく使用できるからで，たとえばメ夕 ンを変性してえた $80 \% \mathrm{H}_{2}+20 \% \mathrm{CO}_{2}$ で溶融炭酸塩 ペースト電解質電池を $600^{\circ} \mathrm{C}$ で作動させ, $24 \mathrm{~W} / \mathrm{ft}^{2}$ 以上の出力密度で $2,000 \mathrm{hr}$ の寿命をえ ${ }^{63)}$ ，この上う な電池では材料費 45 20ドル/kW にもできる64) とい う。なお, 溶融炭酸塩は子食性があり, 蒸発その他で電 池から失われる量が比較的大きく65)，このため電池の 内部抵抗が増加するので, この点をさけるために固体 電解質を用いる研究がおこなわれ， $\left(\mathrm{ZrO}_{2}\right)_{0.91}\left(\mathrm{Y}_{2} \mathrm{O}_{3}\right)$ 0.09 を電解質とする電池が変性ガスで ${ }^{66)},(\mathrm{CeO})_{0.6}$ $\left(\mathrm{LaO}_{1.5}\right)_{0.4}$ 電解質とする電池が直接法で67) 運転さ れた例があるが，ともに $1,000^{\circ} \mathrm{C}$ 付近の高温で作動 させるため電極は白金で, 電池温度の低下が望亡れ る。なお, ガソリンおよび JP-4 などの熱分解による 水素発生装置が発表されている ${ }^{68)}$ 。

\section{V. 石炭燃料電池}

燃料電池から排出される $\mathrm{CO}_{2}+\mathrm{H}_{2} \mathrm{O}$ を石炭で還 元してえられると思われる $\mathrm{CO}+\mathrm{H}_{2}$ で $\left(\mathrm{ZrO}_{2}\right)_{0.85}$ $(\mathrm{CaO})_{0.15}$ を電解質とする電池を白金電極で作動させ, 200ケ直列に結んだ 400 ケの電池群から開路電圧 200 $\mathrm{V}, 1.2 \mathrm{~A}$ で $102 \mathrm{~W}$ の電力が $1,000^{\circ} \mathrm{C}$ でえられてい る ${ }^{69)}$ 。この方法は石炭燃料電池発電所の䄛想につなが る考えである。

\section{VI. 燃料電池の棝題}

燃料電池の応用面の研究は, 運輸機関への適用3227 70)71)を初め種々の考案を生んでいるばかりでなく，工 学的な研究 ${ }^{7273)}$ あるいは経済性 ${ }^{74}$ などの検討がなされ ているが，実用化のためにはな揽多の問題をかかえ ている。 
すなわち，活性度およば耐久度の高い，寿命の長い 安価な触媒の探求，特に白金を使わない触媒が望まれ る。これは安価な燃料電池製造にとつて第 1 条件で, その他, 熱交換器, ポンプその他の付層品の価額低下 が要望される。

また, 工学的な問題としては, 多数の電池を直列ま たは並列に結ぶ技術と各電池への燃料および空気の供 給と放電生成物の除去の均一性保持あるいは熱損失の 低下技術の向上などが望まれる。

しかし民需用として現在最も期待できると思われる 炭化水素空気燃料電池は1970年には生産段階にはいる

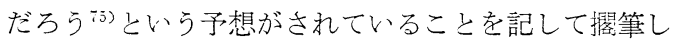
たい。

\section{文献}

1) F. T. Bacon, J. Inst. Fuel, 38, 465(1965)

2) M. Barak, Advan. Energy Conv., 6, 29

3) A. R. Gardner, Prod. Eng., 37, 76

4) E. M. Cohn, Mech. Eng., 88, 22

5) Y. Bréelle Rev. Inst. Fran. Petro., 21, 764

6) E. J. Casey, E. E. Criddle, Chem. Canada, 18,25 「Combust., 2, 10 (1965)

7) J. H. B. George, Proc. J. Int. Etude Pile

8) J. B. Foley, ibid., 2, 38 (1965) 「34, 60

9) T. Takahashi, J. Electro Chem. Soc. Japan,

10) S. G. Meibuhr, Electro Chim. Acta, 11, 1301, 1325

11) R. P. Tischer, ibid., 11, 1309

12) Fuel Cell Systems Amer. Chem. Soc. (1965)

13) W. Vielstich, Brenstoffelemente, Verlag Chemie-Gmbh, Weinheim (1965)

14) Les Piles á Combustible ed. A. Maréchal, Editions Technip, Paris (1965)

15) Hydrocarbon Fuel Cell Technology ed. B. S. Baker, Acad. Press, N. Y. (1965)

16) An Introduction to Fuel Cell ed. K. R. Williams, Elsevier Pub. Co., London

17) Fuel Cells ed. V. B. Bagotskii, Yu. B. Vasilév, Consult. Bureau, N. Y. 「21

18) R. Cohen, Proc. Power Sources Conf., 20,

19) G. C. Szego, I. D. A. Contract SD-50 Task -24, p. 17 (1965)

20) J. L. Platner, P. D. Hess, Chem. Eng. Progress Symp. Series, 61, 299 (1965)

21) Anon, Fronfiers in Fuel Cells, 5, No. 4

22) I. Lindholm, Proc. J. Int. Etude Pile. Combust. 4, 26 (1965)

23) H. Jahnke, ibid., 4, 33 (1965)

24) R. Jasinski, ibid., 4, 38 (1965)

25) K. V. Kordesch, G. E. Evans, ibid., 4, 93 (1965)

26) Anon, Chem. Eng. News, 44, 33

26) E. Tschanter, Elektro-Techn. 48, 250

27) O. Lindstrom, Elec. Rev., 179, 243
28) M. I. Gillibrand, G. R. Lomax, Proc. Power Sounes Conf.. 20, 24

29) C. G. Telschow, Brown Boveri Rev., 53,

30）城上保, 白鳥一, 電化, 34, 442, 646

31) Anon, Frontier in Fuel Cells, 5, No. 1

32) P. Terry et al, Proc. Power Sources Conf., 20, 39

33) E. A. Gillis, ibid., 20, 41

34) R. E. Biddick, D. L. Douglas, 文献 15, p. 131 (1965)

35) H. G. Plust, Brown Boveri Rev., 53, 5

36) W. Vielstich, 文献 15, p. 79 (1965) 「46

37) G. Ciprios, Proc. Power Sources Conf., 20,

38) E. H. Okrent, B. L. Tarmy, Chem. Eng., Progress, 62, $83 \quad$ 「p.121 (1965)

39) P. G. Grimes, H. H. Spengler, 文献 15,

40) K. R. Williams, Direct Current, 11, 42

41) N. I. Palmer et al, 文献 15, p. 151 (1965)

42) H. A. Liebhafsky, Proc. J. Int. Etude Pile. Combust., 1, 41 (1965)

43) H. Binder et al., ibid., 1, 74 (1965)

44) W. T. Grubb, J. Electrchem. Soc., 113, 191

45) L. W. Niedrach, ibid., 113, 645

46) R. Thacker, Nature, 206, 186 (1965)

47) O. J. Adlhart, A. J. Hartner, Proc. Pozver Sources Conf., 20, 11

48) A. C. Makrjdes, ibid., 20, 5 「20, 8

49) J. A. Shrophire, H. H. Horopwitz, ibid.,

50) R. Burshtein et al., Proc. J. Int. Etude Piles Combust., 4, 42 (1965)

51) J. G. Smith, 文献 16, p. 239

52) E. J. Cairns, 文献 15, p. 465 (1965), J. Electro Chem. Soc. 113, 1200

53) J. Meek et al., 文献 15, p. 25 (1965)

54) A. R. Khan et al., Chem. Eng., Progress 62, 74

55) M. L. Engle, ibid., 62, $77 \quad\lceil 20,31$

56) S. J. Bartosh, Proc. Power Sources Conf.,

57) T. G. Kirkland, ibid., 20, 35

58) F. B. Leitz et al, 文献 15 , p. 37 (1965)

59) S. M. Chodosh et al., ibid., p. 495 (1965),

60) G. R. Frysinger, idid., P.9 (1965)

61) M. A. Vertes, A. J, Hartner, Proc. J. Int. Etude Pile Combust., 1, 63 (1965)

62) J. K. Truitt, F. L. Gray, Chem. Eng. Progress, 62, 72

63) I. Trachtenberg, 文献 15, p. 251 (1965)

64) B. S. Baker et al., ibid., p. 293 (1965)

65) G. H. J. Broers et al., ibid., p. 225 (1965)

66) O. Antonsen et al., Brown Boveri Rev., 53. 21

67）高橋武彦ら, 電化，34，205 Proc. $J$. Int. Etude Plie Combust., 3, 42 (1965)

68) J. E. Rothfleisch, L. M. Litz, Proc. Power Sources Conf., 20, 28 
69) D. H. Archer et al., 文献 15, p. 51 (1965)

70) L. D. Gaddy Jr., Proc. Power Sources Corf., 20, 52

「Combust., 1, 19 (1965)

71) G. C. Szego, Proc. J. Int. Etude Pile.

72) G. E. Evans, Chem. Eng. Progress, 62, 69

「bust., 2, 16 (1965)

73) F. Wehrse, Proc. J. Int. Etude Pile Com-

74) I. Verstraete et al., ibid., 1, 9 (1965)

75) Anon, Electron Deuign, 14. 26

\section{5 太陽エネルギ利用の動向}

この一年間における主題利用の動向についてはさし て大きな変化はみられないが，わが国においては太陽 熱温水器の利用が順調に延びているよらである。従来 はそのメーカは比較的中小会社に限られていたが, 最 近は積水, 日立, 松下, 小松などの大会社が生産を開 始しそれぞれ個有の販売ルートにのせて市販してい る。現在，年間生産量はビニール膜で製作した安価な ものが約 20 万個，密閉型や循環型などが約 20 万個，合 計して全国で $40 \sim 45$ 万個の温水器が年間販売されてい る。そして現在全国で使用されている温水器の総数は 約 150 万個に上るものと推定されている。

また，太陽電池を無人灯台や無人中継所に利用する 個数も順調に増加している。表VII-4 は小林正次慶大 教授によつてまとめられた本年 1 月現在の使用実績で ある。
表VII-4 日本におけるシリコン太陽電池の使用個数

使用者用途設置年 数 出力 電池数

$\begin{array}{llllll}\text { 東北電力(株) } & \begin{array}{l}\mathrm{VHF} \\ \text { 中継所 }\end{array} & 1958 & 1 & 70 \mathrm{~W} & 4,320\end{array}$

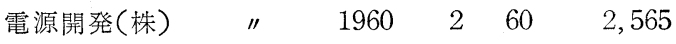

$\begin{array}{llllll}\text { " } & \text { " } & 1961 & 2 & 61.5 & 1,980 \\ \text { " } & \text { " } & 1962 & 1 & 65 & 1,800\end{array}$

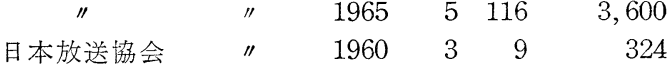

$\begin{array}{llllll}\text { " } 11 & 1961 & 11 & 40.3 & 1,188\end{array}$

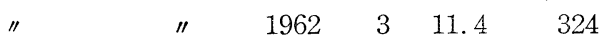

" $\quad$ " $1963 \quad 5 \quad 19.0 \quad 540$

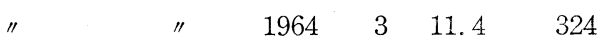

$\begin{array}{llllll}\text { " } & 11 & 1965 & 2 & 7.6 & 216\end{array}$

$\begin{array}{llllll}\text { " } 11 & 1966 & 2 & 7.6 & 216\end{array}$

海上保安庁 燈

$\begin{array}{llll}1960 & 7 & 108.5 & 5,184\end{array}$

$\begin{array}{llll}1961 & 11 & 138.5 & 4,410\end{array}$

$\begin{array}{llll}1962 & 7 & 138.5 & 2,475\end{array}$

$\begin{array}{llll}1963 & 8 & 100.0 & 2,475\end{array}$

$1964 \quad 36 \quad 942.0 \quad 24,408$

航路標識 $1964 \quad 4 \quad 100.0 \quad 2,592$

燈 台 $196524 \quad 943.0 \quad 27,000$

航路標識 $1965 \quad 4 \quad 76.0 \quad 3,760$

燈 台 $1966 \quad 32 \quad 1156.0 \quad 31,203$

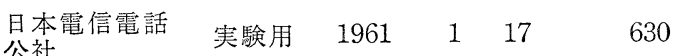

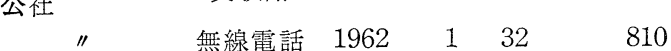

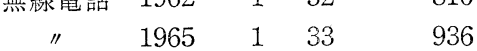

